\title{
Verbeteren van de hulp en ondersteuning aan jeugdigen en gezinnen
}

\author{
R. Bannink
}

Published online: 13 July 2018

(C) Bohn Stafleu van Loghum is een imprint van Springer Media B.V., onderdeel van Springer Nature 2018

De gezonde en veilige ontwikkeling van (kwetsbare) jeugdigen is van groot maatschappelijk belang. De jeugdgezondheidszorg (JGZ) levert hier een belangrijke bijdrage aan. Om deze rol goed te kunnen blijven vervullen is de JGZ volop in ontwikkeling en blijft haar werkwijze telkens verbeteren met onder andere kennis uit wetenschappelijk onderzoek en de praktijk. In dit nummer komt dat ook weer duidelijk naar voren.

Nieuwenhuizen-Struik en collega's bespreken in hun artikel de wetenschappelijke onderbouwing van het advies om hoog-allergene voeding vroeg te introduceren. Ouders consequent aanmoedigen om bijvoeding vroeg te starten kan namelijk voedselallergie voorkomen, zo blijkt uit wetenschappelijk onderzoek. Bij kinderen met ernstig eczeem kan een huidpriktest bijdragen aan de beoordeling of thuisintroductie veilig is. Om de vroege introductie van hoog-allergene voeding bij zuigelingen tot een succes te maken is volgens de onderzoekers opname in de geldende richtlijnen binnen de JGZ nodig.

Een richtlijn die recentelijk is gepubliceerd in de JGZ is de richtlijn Heupdysplasie. Konijnendijk en collega's beschrijven deze richtlijn. Het doel van deze richtlijn is het ondersteunen van het eenduidig handelen van de JGZ-professional bij de vroegtijdige opsporing van heupdysplasie, door geprotocolleerde screening en tijdige verwijzing voor aanvullende diagnostiek. Tot nu toe werden binnen de JGZ namelijk verschillende definities gebruikt voor risicofactoren, werden signaleringsinstrumenten niet uniform toegepast, en ontbrak het aan eenduidig beleid over wanneer en naar wie moet worden doorverwezen.

\section{R. Bannink (ه)}

Centrum voor Jeugd en Gezin Rijnmond, Rotterdam,

Nederland

R.Bannink@cjgrijnmond.nl
In dit nummer worden ook twee proefschriften en de meerwaarde voor de JGZ-praktijk besproken.

De Beer heeft onderzocht of babyvoeding en vroege groei op baby- tot kleuterleeftijd al geassocieerd zijn met cardiovasculaire risicofactoren, zoals hoge bloeddruk. Bezem heeft onderzoek gedaan naar triage en het effect hiervan op het bereik, de mate van signalering en de extra geleverde zorg aan kinderen met (mogelijke) risicofactoren. Hiermee is een werkwijze onderzocht waarbij ruimte gecreëerd is om meer vraaggerichte zorg te kunnen inzetten door minder inzet op de basisonderzoeken. De vrijgespeelde ruimte gaf onder andere meer mogelijkheden voor jeugdartsen en jeugdverpleegkundigen om samen te werken met partners in het onderwijs, het sociale domein en de curatieve zorg.

Met het anders en flexibeler inrichten van de contactmomenten zijn veel JGZ-organisaties bezig. Deze ontwikkeling is al een tijdje aan de gang, maar loopt nog volop. Hiermee wordt getracht de hulp en ondersteuning aan jeugdigen en gezinnen te blijven verbeteren. Het koppelen van onderzoek aan dit soort initiatieven kan een belangrijke bijdrage leveren aan de onderbouwing van de JGZ.

Dat samenwerking een belangrijke bijdrage kan leveren aan het verbeteren van de zorg aan jeugdigen komt ook naar voren in het artikel van Custers en collega's. In dit onderzoek werden alle kinderen die binnen kwamen bij de vrouwenopvang systematisch in kaart gebracht middels een gestandaardiseerde anamnese en lichamelijk onderzoek. Intensieve samenwerking met de JGZ bleek hierbij essentieel.

$\mathrm{Al}$ met al dus weer volop informatie in dit nummer om de zorg aan jeugdigen en gezinnen te blijven verbeteren!

Rienke Bannink 